\title{
Effects of Slash on Herbaceous Communities in Pinyon-Juniper Woodlands of Northern Arizona
}

\author{
Michael T. Stoddard, ${ }^{1}$ David W. Huffman, ${ }^{2}$ Thom M. Alcoze, ${ }^{3}$ and Peter Z. Fulé \\ Authors are ${ }^{1}$ Research Specialist, ${ }^{2}$ Research Associate, and ${ }^{4}$ Director of Operations and Associate Professor, Ecological Restoration Institute, Northern \\ Arizona University, Flagstaff, AZ 86011, USA; and ${ }^{3}$ Professor, School of Forestry, Northern Arizona University, Flagstaff, AZ 86011, USA.
}

\begin{abstract}
Scattering slash (downed woody materials) after tree removal is increasingly prescribed by land managers as a treatment to promote the establishment and growth of understory vegetation in pinyon-juniper woodlands. However, the effects of scattering slash on soil resources and plant communities are poorly understood and often confounded with the release from tree competition. In order to examine how slash affects plant establishment, soil stability, soil nutrients, and soil microbiota, we initiated a $2 \times 2$ full factorial experiment with two levels of seeding and two levels of slash additions within 30 intercanopy spaces, repeated at two intact pinyon-juniper woodland sites with different soil characteristics in northwestern Arizona. Pretreatment data were collected in 2003 and posttreatment responses were measured in 2004 and 2005. Total plant cover increased within all treatments; however, grasses increased significantly only in the seed-and-slash treatment at both sites. In addition, a greater proportion of seed-and-slash plots contained more reproductively active grasses compared to seed-only plots. Slash treatments also resulted in significantly less sediment movement compared to nonslash treatments. Changes in soil nutrients were not observed, except available $\mathrm{NO}_{3}-\mathrm{N}$ decreased significantly in slash treatments. Arbuscular mycorrhizal potential and microbial biomass carbon increased as a result of the slash treatment. Addition of woody materials appeared to have general effectiveness at improving the ecological function of soils and promoting understory establishment and thus may be considered a desirable treatment for improving degraded conditions.
\end{abstract}

\section{Resumen}

La dispersión de la tala (materiales leñosos derribados) después de la remoción del árbol es prescrita cada vez más por los administradores de tierras como un tratamiento para promover el crecimiento y el establecimiento de la vegetación del sotobosque en los bosques de pino piñonero y enebro. Sin embargo, los efectos de la dispersión de la tala en las comunidades de plantas y en los recursos del suelo son pobremente comprendidos y a menudo confundidos con la liberación de la competencia arbustiva. En orden para examinar como la tala afecta el establecimiento de la planta, la estabilidad del suelo, los nutrientes del suelo y la micro biota del suelo, nosotros iniciamos un experimento factorial completo $2 \times 2$ con dos niveles de siembra y dos niveles de adicción de tala en 30 espacios dentro del dosel, repitiéndolo en dos sitios intactos de bosque de pino piñonero y enebro de diferentes características de suelo en el noroeste de Arizona. Los datos previos al tratamiento fueron colectados en el 2003 y las respuestas posteriores al tratamiento fueron medidas en el 2004 y 2005 . La cobertura vegetal total aumentó en todos los tratamientos, sin embargo las hierbas aumentaron significativamente sólo en el tratamiento de semilla y tala en ambos sitios. Además, una mayor porción de parcelas semillas y tala contuvieron más hierbas reproductivamente activas comparadas a las parcelas de solo semilla. Los tratamientos de tala también resultaron significativamente en menos movimiento de sedimento comparado a los tratamientos de no tala. No se observaron cambios en los nutrientes del suelo, excepto el $\mathrm{NO}_{3}-\mathrm{N}$ disponible que disminuyó significativamente en los tratamientos de tala. El potencial micorrízico arbuscular y el carbono en la biomasa microbiana se incrementaron como resultado al tratamiento de tala. La adicción de los materiales leñosos parece tener una efectividad general en mejorar la función ecológica de los suelos y en promover el establecimiento del sotobosque, y de este modo se podría considerar como un tratamiento conveniente para mejorar las condiciones degradadas.

Key Words: down woody material, ecological restoration, pinyon-juniper woodlands, safe site, slash mulch, understory production

\section{INTRODUCTION}

The in-filling of trees into adjacent intercanopy openings over the past century has raised concerns for conserving the ecological integrity of many pinyon-juniper woodlands (Cot-

Research was funded in part by the Bureau of Land Management, the Ecological Restoration Institute, and the US Department of Agriculture Forest Service.

Correspondence: Michael T. Stoddard, Ecological Restoration Institute, Northern Arizona University, PO Box 15017, Flagstaff, AZ 86011, USA. Email: Mike.Stoddard@nau.edu

Manuscript received 9 August 2007; manuscript accepted 30 June 2008 tam and Stewart 1940; Tausch et al. 1981; Harris et al. 2003; Weisberg et al. 2007). The heterogonous structure often associated with intact pinyon-juniper woodlands is developing into a continuous canopy structure with high fuel loads (West 1984; Evans 1988; Tausch 1999; Romme et al. 2003). Close temporal association between intense grazing pressures and tree expansion, both beginning in the late 1800s, suggest livestock grazing may have facilitated the depletion of herbaceous biomass within portions of northern Arizona (Altschul and Fairly 1989). As a result, understory patches are being displaced by tree species, which is altering ecosystem processes 
and leading to degraded ecological conditions (Schlesinger et al. 1990; Callaway 1995; Tausch and West 1995). Undesirable conditions are typically indicated by sparse ground cover, erosion of topsoils, loss of native understory abundance and species richness, depletion of soil seedbanks, disruption in hydrological processes, and altered disturbance regimes (Wood et al. 1987; Pieper 1990; Poulsen et al. 1999; Miller and Tausch 2001; Wilcox et al. 2003). However, with such an extensive range and variety of habitats, the condition of pinyon-juniper woodlands spans from relatively pristine to heavily degraded (Miller et al. 1999; Romme et al. 2003). Specific examples described as relatively intact pristine woodlands include portions of Mesa Verde in southwestern Colorado and isolated mesas in northern Arizona and southern Utah, all of which consist of a mosaic structure with distinct groups of all-aged trees, separated by open intercanopy patches with an assortment of native understory species and little soil erosion (Jameson et al. 1962; Schmutz et al. 1967; Thatcher and Hart 1974; Floyd et al. 2000).

Plant community recovery is possible if sufficient native understory pools exist, both above ground and in the soil seedbank. In degraded pinyon-juniper woodlands, soil seedbanks are depleted, and understory plant recruitment is limited (Koniak and Everett 1982; Call and Roundy 1991; Poulsen et al. 1999). The recovery of understory populations could be accelerated with the application of seeds, although seeding can be expensive and have unpredictable effectiveness (Poulsen et al. 1999; Chambers 2000).

Scattering slash that is generated when trees are thinned or pruned has been found to improve the ecological function of soils and accelerate the establishment of herbaceous communities in semiarid woodlands (Tongway and Ludwig 1996; Breshears et al. 1998; Jacobs and Gatewood 1999; Wood and Javed 2001; Hastings and Javed 2001; Hastings et al. 2003). Unfortunately, understory responses to slash additions are frequently confounded with reduced overstory competition that results from tree thinning. Scattered slash is likely to promote plant establishment and growth by ameliorating harsh microclimates, increasing soil moisture, impeding erosion of topsoil, and trapping windblown seeds and organic debris (Herman et al. 1995; Tongway and Ludwig 1996; Jacobs and Gatewood 1999; Brockway et al. 2002; Hastings et al. 2003). However, accumulation of needles may negatively effect germination by reducing soil-seed contact and through the release of chemical inhibitors (Jameson 1970; Chambers 2000; Horman and Anderson 2003). Inputs of organic matter can also stimulate increases in microbial populations, thus enhancing soil structure and soil-plant interactions (Ludwig and Reynolds 1988; Schlesinger et al. 1990; Herman et al. 1995), but may also contribute to the immobilization of soil nutrients, which may inhibit plant growth (Murty et al. 1996). Furthermore, soil characteristics can also affect herbaceous communities by trapping and retaining seeds and influencing soil water potential and nutrient dynamics (Harper et al. 1965, Chambers 2000). It is therefore important to understand site characteristics as well as ameliorations such as slash treatments' influences on understory responses. Nonetheless, there is insufficient evidence documenting impacts of residual woody materials on improving soil conditions and improving native plant communities and often these results are confounded with other treatments, thus reducing the generalizations of these results.

The specific objectives of our study were to 1) evaluate the effects of slash additions on soil movement, 2) quantify the effects of slash addition on soil chemistry and soil biota, and 3) assess the effectiveness of slash additions on native grass emergence and establishment. Grasses are of particular interest because root biomass associated with grasses is likely to help in soil stabilization (West 1999). We hypothesized that slash additions would decrease soil movement and increase nutrient availability and mycorrhizal and soil microbial potential, which would improve soil conditions and support the establishment of native perennial graminoids within intercanopy openings.

\section{METHODS}

\section{Study Area}

Our study was conducted 2003-2005 at Grand CanyonParashant National Monument near Mount Trumbull in northwest Arizona. In 2004, we established identical experiments at two sites, each representing characteristic soil types in pinyonjuniper woodlands of this region. The first site we refer to as the "clay-loam" site (lat $36^{\circ} 26^{\prime} \mathrm{N}$, long $113^{\circ} 09^{\prime} \mathrm{W}$ ) where soils were fine, smectitic, mesic aridic Argiustolls (DeWall 1993). Major management factors for the clay-loam site included slow water permeability, high shrink-swell soils, and high available water capacity (DeWall 1993). At the second site, which we refer to as the "cinder" site (lat $36^{\circ} 24^{\prime} \mathrm{N}$, long $113^{\circ} 12^{\prime} \mathrm{W}$ ), soils had ashyskeletal surface texture over fragmental or cindery, mixed, mesic vitrandic Haplustepts. Major management factors for this site included moderate to high water permeability, and very low available water capacity (DeWall 1993). Elevation of both sites ranges from approximately $1900 \mathrm{~m}$ to $1950 \mathrm{~m}$.

Climate data, compiled from the Nixon Flats Remote Automated Weather Station site at Mount Trumbull, Arizona $(1980 \mathrm{~m})$, indicated that mean annual precipitation for the last decade (1992-2005) was $429 \mathrm{~mm}$. Total annual precipitation during the field experiment in 2004 and 2005 was $448 \mathrm{~mm}$ and $919 \mathrm{~mm}$, respectively. Precipitation patterns for the region follow a bimodal distribution with monsoonal rains in July through September and snowfall in the winter months. Precipitation during the summer monsoon falls primarily during short-duration, high-intensity storms, which can result in relatively severe soil erosion.

Vegetation at the sites is classified as Great Basin Cold Temperate Woodland (Brown 1994). Mixed-aged stands of pinyon pine (Pinus edulis Engelm.) and Utah juniper (Juniperus osteosperma Torr.) dominated the two sites and ranged in density from 638 trees $\cdot \mathrm{ha}^{-1}$ to 832 trees $\cdot \mathrm{ha}^{-1}$ (D. W. Huffman, M. T. Stoddard, P. Z. Fulé, W. W. Covington, and H. B. Smith, unpublished data, 2005). Tree densities are presently four times greater than estimated in 1870 (D. W. Huffman, M. T. Stoddard, P. Z. Fulé, W. W. Covington, and H. B. Smith, unpublished data, $2005)$ and understory conditions are in poor condition. Historical evidence indicates intense livestock grazing at the sites commenced around 1870 and continued until the 1980s (Altschul and Fairly 1989). A range inspection report from 1969 stated that all three allotments in the area were in very poor condition and utilization of grasses was around $100 \%$ each season (Bureau of Land 
Management District Office, St George, UT, unpublished report, 1969). Soil seedbanks were relatively depleted with less than 200 seeds $\cdot \mathrm{m}^{-2}$ (D. W. Huffman, M. T. Stoddard, P. Z. Fulé, W. W. Covington, and H. B. Smith, unpublished data, 2005). Active soil erosion was clearly evident throughout both sites. Common understory species at the sites included purple bird's peak (Cordylanthus pariviflorus [Ferris] Wiggins), sulphur-flower buckwheat (Eriogonum umbellatum Torr.), slimflower scurfpea (Psoralidium tenuiflorum [Pursh] Rydb.), and fineleaf hymenopappus (Hymenopappus filifolius Hook.).

\section{Experimental Design}

At each site, a full factorial design with two levels of seeding (no seed, seed) and two levels of slash materials (no slash, slash) was added in canopy openings (interspaces) that ranged in size from 0.02 ha to 0.05 ha. Fifteen interspaces were randomly selected at each of the two study sites. Four $1 \times 1 \mathrm{~m}$ permanent plots were randomly established in each interspace. Plots were placed at least $2 \mathrm{~m}$ apart and at least $3 \mathrm{~m}$ from the edge of any tree crown. We randomly assigned one of the following treatments to each plot: 1) control, 2) seed, 3) slash, or 4) seed + slash. Treatments were applied in early August 2003 to coincide with monsoonal rains.

Seeding mixture comprised equal weights of the following four native grasses: 1) Indian ricegrass (Achnatherum hymenoides [Roemer and J. A. Schultes] Barkworth); 2) purple threeawn (Artistida purpurea Nutt.); 3) bottlebrush squirreltail (Elymus elymoides [Raf.] Swezey subsp. elymoides); and 4) sideoats grama (Bouteloua curtipendula [Michx.] Torr.). These species were selected to represent a seed mix land managers may use for pinyon-juniper restoration. All selected species were observed near or within the study sites. Seeds were thoroughly mixed and hand broadcast at a rate of $9.7 \mathrm{~g} \cdot \mathrm{m}^{-2}$. For slash treatments, slash materials were collected by pruning juniper trees located at least $50 \mathrm{~m}$ away from the interspaces. Pruned material was less than $7.6 \mathrm{~cm}$ in diameter and less than $1 \mathrm{~m}$ in length. Slash amounting to $9.0 \mathrm{~kg} \cdot \mathrm{m}^{-2}$ fresh weight was placed on plots after seeding was completed. This amount of slash created beds of approximately $0.6 \mathrm{~m}$ in depth.

\section{Field Methods}

Foliar cover of each species and soil substrate on each plot was ocularly estimated during the month of August in 2003 (pretreatment), 2004 (posttreatment), and 2005 (posttreatment). We also counted plant individuals on plots during each sampling period. In 2005, individual grass plants were examined for the presence of inflorescences. Plant nomenclature followed the US Department of Agriculture Plants Database (US Department of Agriculture Natural Resources Conservation Service 2004).

Soil movement was estimated using erosion bridge measurements (Shakesby 1993; Brockway et al. 2002). Prior to treatments, two permanent stakes were placed $1 \mathrm{~m}$ apart along the downhill edge of each plot. Stakes were driven into the soil and then cemented with approximately $5 \mathrm{~cm}$ extending above the ground. An angle iron (bridge) was placed on top of the stakes at each plot and the height from the bridge to the soil surface was measured at three fixed points using a $15-\mathrm{cm}$ square with a builtin level. We averaged the three measurements in order to estimate bridge height and subsequent gain or loss of soil.
We collected three soil samples from random locations within each plot in August 2003 and 2004. Soils were collected to a depth of $10 \mathrm{~cm}$ using a soil core $4.2 \mathrm{~cm}$ in diameter. All soil samples were collected in August each year in order to control for season variation in soil properties. Soil samples from each plot were composited and subsamples of the composites were analyzed for arbuscular mycorrhizae potential (AMP) and soil chemistry. Additional samples were also collected from control and slash plots in August 2004 to determine microbial biomass carbon $(\mathrm{C})$.

\section{Soil Analysis}

Soil Biota. To test for AMP, sampled soil was placed into $4 \times$ $20 \mathrm{~cm}$ Conetainers (Stuewe and Sons, Inc., Corvallis, OR) within $24 \mathrm{~h}$ of field collection and used for bait-plant bioassays (Brundrett and Abbott 1994). Corn (Zea mays L.) seeds were germinated and then placed in the Conetainers as bait plants for mycorrhizal fungi. We used corn as the host plant, because it is mycotrophic with a variety of fungal species and its growth is relatively fast and uniform in a range of soil types (Johnson et al. 1999). Corn plants were harvested after $5 \mathrm{wk}$. Roots of these plants were cut into 2.5 -cm segments and a random subsample of these segments was cleared using a potassium hydroxide solution and then stained in $0.5 \%$ Shaeffer ink (Vierheilin et al. 1998). Stained root segments were examined under a dissecting microscope and AMP colonization was quantified for each segment using the gridline-intersect method (Johnson et al. 1999). This method detects a range of inoculum sources and is considered a more reliable method for quantifying total density of AMP propagules than direct counts of spores or colonized root lengths (Brundrett and Abbott 1994; Johnson et al. 1999).

Soil microbial C was determined using the chloroform fumigation-extraction method (Brooks et al. 1985; Grady and Hart 2006). Organic C concentrations in unfumigated and fumigated extracts were determined by ultraviolet-enhanced persulfate oxidation using a Dohrmann DC-80 carbon analyzer with infrared detection (Tekmar-Dohrmann, Cincinnati, $\mathrm{OH}$ ). Microbial $\mathrm{C}$ was calculated by subtracting organic $\mathrm{C}$ in the unfumigated extracts from organic $\mathrm{C}$ in the fumigated extracts and dividing by 0.39 (Grady and Hart 2006).

Soil Chemistry. Composite soil samples from each plot were analyzed for $\mathrm{pH}$, total nitrogen $(\mathrm{N})$, organic $\mathrm{C}$, and available $\mathrm{NO}_{3}-\mathrm{N}$ (nitrate) and $\mathrm{NH}_{4}-\mathrm{N}$ (ammonium). Soil $\mathrm{pH}$ was determined in 1:1 soil:water slurry using a $\mathrm{pH}$ meter. Air-dried soils were grounded with a mortar and pestle and then analyzed for total $\mathrm{N}$ and organic C concentrations using a FLASH EA 1112 Elemental Analyzer (CE Elantech Inc., Lakewood, NJ). Available $\mathrm{NO}_{3}-\mathrm{N}$ and $\mathrm{NH}_{4}-\mathrm{N}$ was determined by potassium chloride extraction of freshly collected soil by automated colorimetry using a Technicon Autoanalyzer (Parkinson and Allen 1975). $\mathrm{NO}_{3}-\mathrm{N}$ and $\mathrm{NH}_{4}-\mathrm{N}$ analyses were only conducted on 2004 posttreatment soil samples.

\section{Statistical Analyses}

Vegetation. Treatment effects on vegetation and substrate cover were analyzed using Kruskal-Wallis nonparametric tests. Following statistically significant results $(P<0.05)$, Mann- 
Whitney tests were used to make pairwise treatment comparisons. Alpha levels for pairwise tests were adjusted using a Bonferonni correction (Kuehl 1994). Proportions of reproductively active grasses were compared between slash and nonslash plots with $\chi^{2}$ tests. We also used linear regression to examine the relationship between soil movement (absolute value) and total cover from nonslash plots. Prior to analysis, total percentage of cover data were $\log (n+1)$ transformed to meet the normality assumption.

Soils Biota and Chemistry. Effects of treatment and time on soil movement were analyzed using multivariate analysis of variance for repeated measures tests. One-way analysis of variance was used to test treatment effects on AMP and soil chemistry variables. Paired $t$ tests were used to assess differences between control and slash-only treatment means for microbial biomass carbon. We used the Shapiro-Wilks test to evaluate normality and Levene's test to assess homoscedasticity of variance. Prior to analysis, $\mathrm{NO}_{3}-\mathrm{N}$ data and $\mathrm{AMP}$ data were square-root transformed to meet the normality assumption. If a significant result occurred, we used Tukey's honestly significant difference test to compare treatment differences within years All tests were conducted at alpha $=0.05$ using JMP-IN software (version 5.1.2; SAS 2004).

\section{RESULTS}

\section{Vegetation Response}

Prior to treatment, no distinguishable differences were recorded in total understory cover among treatments at either site. Average understory cover was less than $2 \%$ at the clay-loam site and $0.5 \%$ at the cinder site (Table 1). Grass cover comprised less than $0.1 \%$ at both sites (Table 1 ).

In 2004, treatment differences for understory functional groups were limited to grasses, exotics, and perennial forbs at the clay-loam site (Table 1; Fig. 1). Grass foliar cover and density (number of individuals $\cdot \mathrm{m}^{-2}$ ) was significantly higher $(P<0.0001$ and $P<0.0001$, respectively $)$ in the seed-and-slash treatment compared to the other three treatments (Fig. 1). Grass cover represented $43 \%$ of the total cover $(2.1 \%)$ in the seed-and-slash treatment, $8 \%$ in the seed-only treatment, and $2 \%$ in the control plots. However, overall grass cover and density on the site remained very low at $<1 \%$ and $<8$ indiviuals $\cdot \mathrm{m}^{-2}$, respectively. Exotic species cover was significantly higher $(P=0.006)$ in the control and seed-only treatments. This difference was driven by increases in little hogweed (Portula oleraces L.), a shade-intolerant annual.

In 2005 , total vegetation cover increased by at least $300 \%$ in all of the treatments when compared to the previous year; however, treatment differences were restricted to grasses and exotics functional groups at the clay-loam site (Table 1). Grass foliar cover and density was once again higher $(P<0.0001$ and $P<0.0001$, respectively) in the seed-and-slash treatment compared to the other three treatments (Fig. 1). Exotic cover continued to be significantly $(P=0.007)$ higher in both nonslash treatments; however, all treatments showed slight decreases in exotic cover when compared to the previous year.

Total understory cover at the cinder site increased across all treatments in both posttreatment sampling years (Table 1).

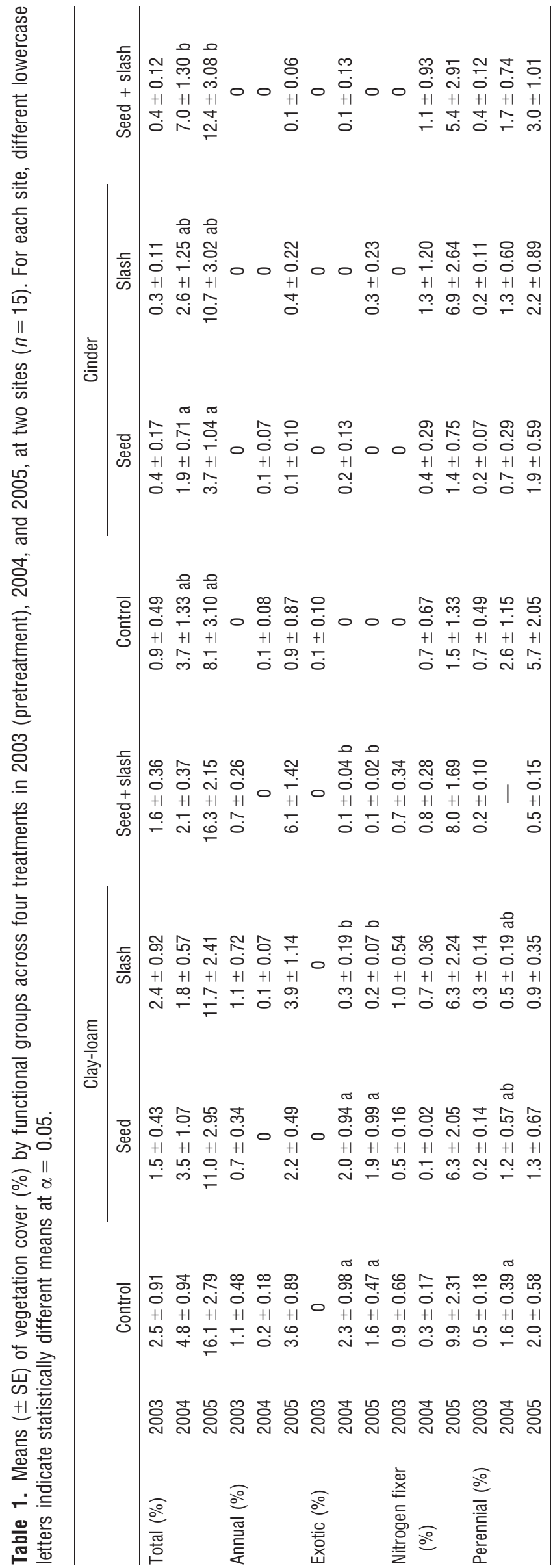



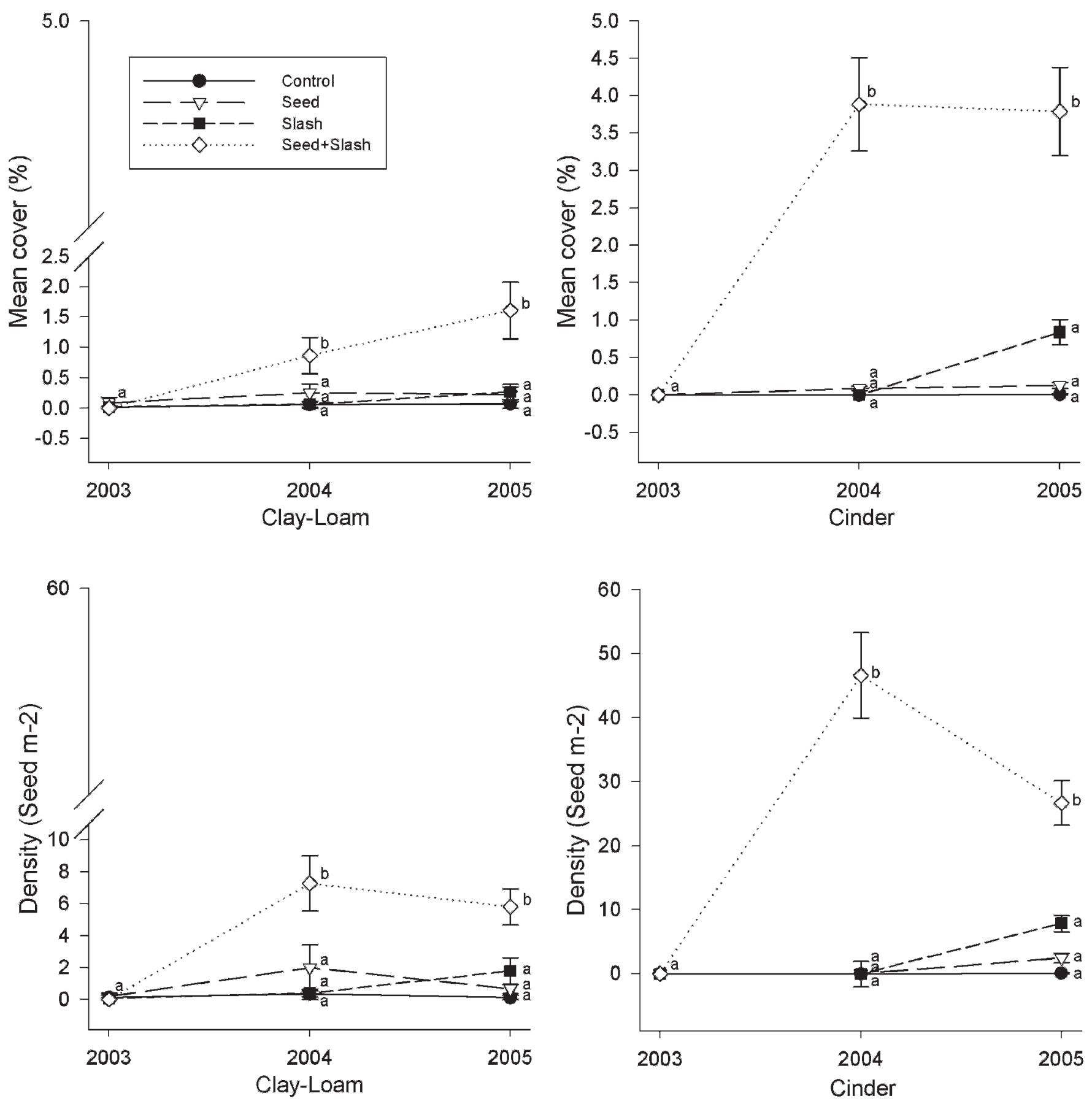

Figure 1. Mean cover (\%) and number of individual seeded grasses under experimental treatments in 2003, 2004, 2005, pretreatment, 12 mo, and 24 mo posttreatment at the clay-loam and cinder sites. Values indexed within each year by a different letter are significantly different at $\alpha=0.05$. Bars represent \pm 1 standard error of the mean $(n=15)$.

Significant treatment effects were apparent in total cover with the greatest increases resulting in the seed-and-slash treatment in both 2004 and 2005 ( $P=0.002$ and $P=0.04$, respectively). Treatment effects on grass cover and density at the cinder site were similar to those at the clay-loam site though more pronounced (Fig. 1). Both cover and density were significantly greater $(P<0.0001$ and $P<0.0001$, respectively) in the seedand-slash plots compared to the other treatments in 2004. Both variables were also significantly greater $(P<0.0001$ and $P<0.0001$, respectively) in 2005 in the seed-and-slash plots. However, almost a twofold reduction of individuals per square meter and a $0.1 \%$ decrease in foliar cover were observed in seed-and-slash plots in 2005, whereas the slash treatment increased from no cover in 2004 to an average of $0.8 \%$ cover in 2005. Grass species encountered at both sites and during both posttreatment years were Elymus elymoides, Bouteloua curtipendula, and Aristida purpurea, all of which had been seeded. Achnatherum hymenoides was also seeded but no seedlings were found on experimental plots.

Proportions of reproductively active grasses were statically greater in slash plots compared to nonslash plots at both the clay-loam and cinder sites $(P<0.005$ and $P<0.001$, respec- 
Table 2. Means ( \pm SE) of litter and soil cover (\%) across four treatments in 2003 (pretreatment) and 2004 (first year posttreatment), at two sites $(n=15)$. Row means indexed by a different letter are statistically different at $\alpha=0.05$.

\begin{tabular}{|c|c|c|c|c|}
\hline & Control & Seed & Slash & Seed + slash \\
\hline & - & ----------" & 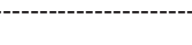 & 自 \\
\hline \multicolumn{5}{|c|}{ Litter cover (\%) } \\
\hline 2003 & $0.55 \pm 0.50$ & $0.28 a \pm 0.27$ & $0.28 \pm 0.14$ & $0.07 \pm 0.04$ \\
\hline 2004 & $2.20 \pm 1.03 a$ & $1.17 a \pm 0.68 a$ & $86.15 \pm 2.50 b$ & $88.31 \pm 1.71 b$ \\
\hline \multicolumn{5}{|c|}{ Mineral soil (\%) } \\
\hline 2003 & $99.36 \pm 0.40$ & $99.60 \pm 0.27$ & $99.63 \pm 0.14$ & $99.85 \pm 0.04$ \\
\hline 2004 & $97.69 \pm 1.03 \mathrm{a}$ & $98.71 \pm 0.69 \mathrm{a}$ & $13.77 \pm 2.50 b$ & $11.37 \pm 1.71 b$ \\
\hline \multicolumn{5}{|c|}{ Litter cover (\%) } \\
\hline 2003 & $0.21 \pm 0.14$ & $0.19 \pm 0.13$ & $0.40 \pm 0.22$ & $0.58 \pm 0.32$ \\
\hline 2004 & $1.00 \pm 0.50 \mathrm{a}$ & $0.60 \pm 0.27 a$ & $89.80 \pm 2.37 b$ & $92.63 \pm 0.85 b$ \\
\hline \multicolumn{5}{|c|}{ Mineral soil (\%) } \\
\hline 2003 & $99.88 \pm 0.14$ & $99.73 \pm 0.13$ & $99.54 \pm 0.22$ & $99.34 \pm 0.32$ \\
\hline 2004 & $99.92 \pm 0.50 \mathrm{a}$ & $99.31 \pm 0.27 \mathrm{a}$ & $10.11 \pm 2.37 b$ & $6.40 \pm 0.85 b$ \\
\hline
\end{tabular}

tively). Across all slash plots, $40 \%$ and $43 \%$ had at least one grass individual that was reproductively mature, whereas $3 \%$ and $10 \%$ of the seed plots contained a reproductive grass species (clay-loam and cinder site, respectively).

\section{Litter Cover, Soil Exposure, and Soil Movement}

Prior to treatment, no differences were evident in litter and mineral soil cover at either the clay-loam or the cinder sites (Table 2). Bare soil cover averaged $99 \%$ and litter cover was less than $1 \%$ at both sites (Table 2). One year following treatment, litter cover significantly increased in slash plots compared to nonslash plots at both the clay-loam and the cinder sites $(P<0.0001$ and $P<0.0001$, respectively). Litter cover in slash plots averaged $87 \%$ and $91 \%$ at clay-loam and cinder sites, respectively (Table 2).

Soil movement on plots where slash was added was significantly lower at both the clay-loam and the cinder sites $(P<0.0001$ and $P<0.0001$, respectively) compared to nonslash plots for both posttreatment sampling years (Fig. 2). At the clay-loam site, 2-yr mean soil loss for slash plots was $10.0 \mathrm{~mm}$ compared to $28.5 \mathrm{~mm}$ for nonslash plots. At the cinder site, 2-yr mean soil movement for slash plots was $12.0 \mathrm{~mm}$ and $30.3 \mathrm{~mm}$ in nonslash plots. Average soil movement on plots where we added slash was almost three times lower than on plots without slash. Considerable year-toyear variation occurred in soil movement; nevertheless, soil movement in both sampling years was significantly lower in slash treatments compared to nonslash treatments at both sites (Fig 3). Incorporating only nonslash plots, soil movement was also negatively correlated with vegetation cover at each site (Fig. 4).

\section{Soil Biota}

Mycorrhizal fungi colonized all corn bait-plants in 2003 and 2004. Prior to treatment, no significant differences in AMP were detected between treatment groups at either site. On average, AMP at the clay-loam and cinder sites was $11.3 \%$ and $11.7 \%$, respectively, before treatment. One year following treatment, AMP was significantly greater $(P<0.0001$ and
$P<0.0001)$ for soils from slash plots compared to nonslash plots at both sites (Fig. 5). Percentage of root length colonized by arbuscular mycorrhizae (AM) fungi in slash plots was more than two times greater than in nonslash plots at both sites. No statistical differences were evident between the slash and the seed-and-slash treatments at either site for AMP. Microbial biomass C in soil samples collected in 2004 was also significantly greater in slash plots compared to control plots at both the clay-loam and cinder sites $(P<0.0001$ and $P=0.036$, respectively; Fig. 6).

\section{Soil Chemistry}

Prior to treatment, we found no significant differences in soil $\mathrm{pH}$, total $\mathrm{N}$, or organic $\mathrm{C}$ between treatments at either site (Table 3). Soil $\mathrm{pH}$ at both sites was approximately 7.7. Organic $\mathrm{C}$ averaged across all treatments at the clay-loam and cinder sites was $8.4 \mathrm{~g} \cdot \mathrm{kg}^{-1}$ and $10.3 \mathrm{~g} \cdot \mathrm{kg}^{-1}$, respectively. Total $\mathrm{N}$ averaged less than $1.0 \mathrm{~g} \cdot \mathrm{kg}^{-1}$ at each site. $\mathrm{NO}_{3}-\mathrm{N}$ was

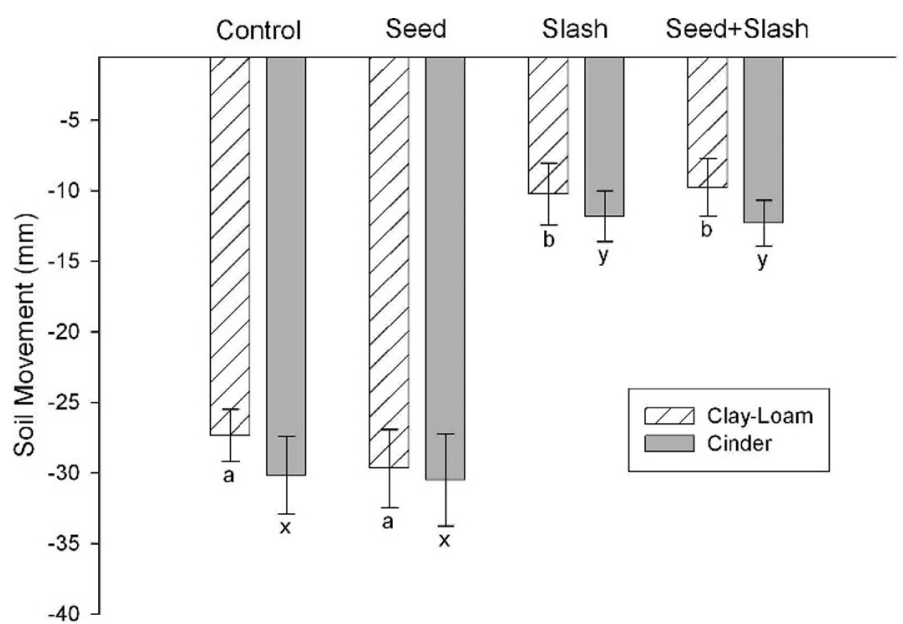

Figure 2. Mean soil movement $(\mathrm{mm})$ under experimental treatments at two different sites. Values indexed by a different letter are statistically different at $\alpha=0.05$ within each site. Bars represent \pm 1 standard error of the mean $(n=15)$. 

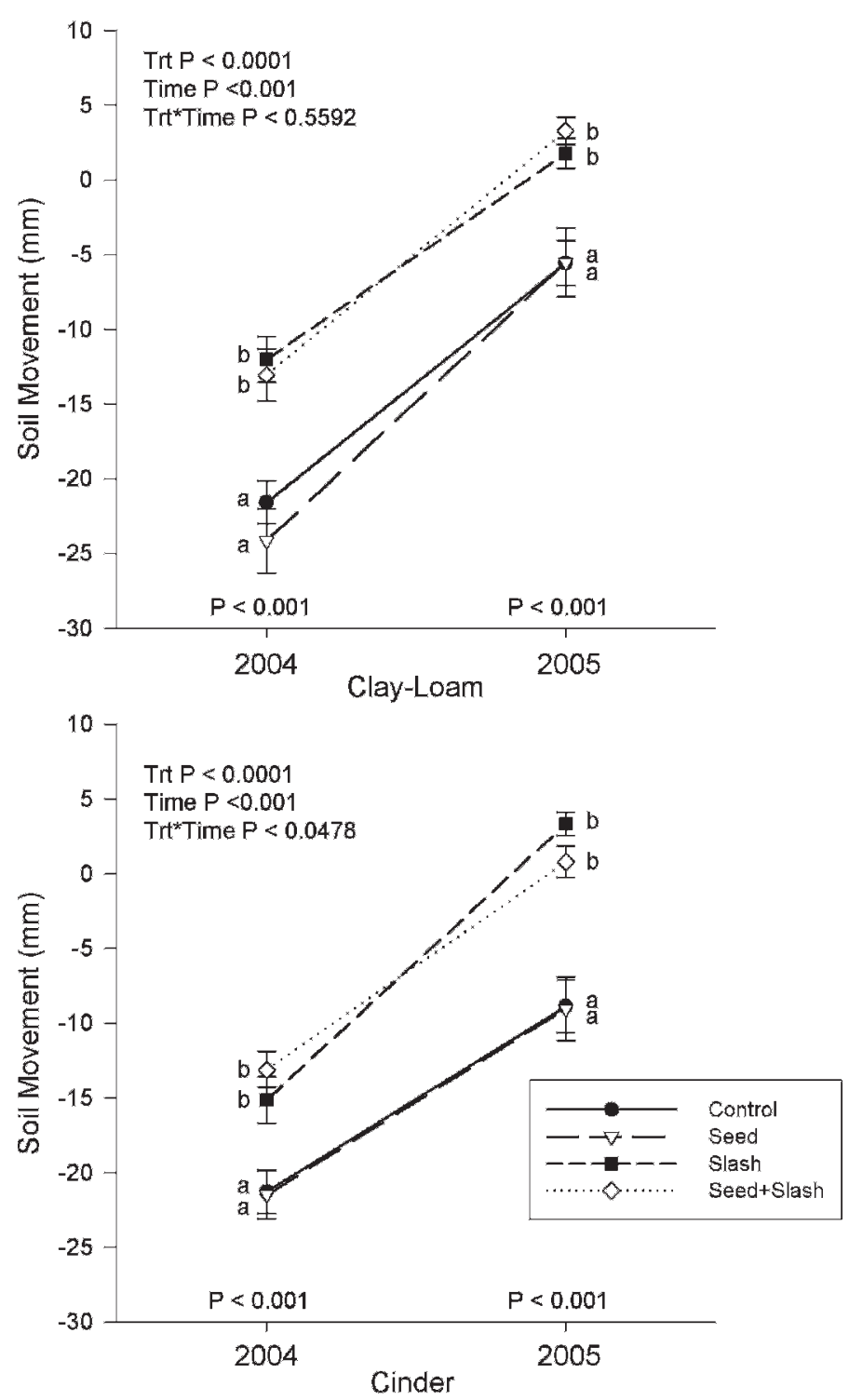

Figure 3. Soil movement $(\mathrm{mm})$ plotted through time for all four treatments at two different sites. Values indexed by a different letter are statistically different at $\alpha=0.05$ within each site. Bars represent \pm 1 standard error of the mean $(n=15)$.

significantly lower for both the clay-loam site $(P<0.0001)$ and cinder site $(P<0.0001)$ on plots with slash compared with nonslash plots $1 \mathrm{yr}$ after treatment (Table 3).

\section{DISCUSSION}

\section{Vegetation Response}

The seed-and-slash treatment led to a higher percentage of grass cover, greater seedling emergence, and more reproductive shoots on plants compared to the other treatments.

Although total grass cover was low $2 \mathrm{yr}$ after treatment, cover significantly increased across all seed-and-slash plots, expanding from $<0.1 \%$ to as high as $3.9 \%$. Grass composition was composed primarily of seeded species and accounted for $19 \%$ of the total cover $(14.3 \%)$ and $49 \%$ of total density across all seedand-slash plots. Our results are consistent with other soil amelioration studies using slash in pinyon-juniper woodlands and demonstrate the benefits of this approach for increasing grass establishment (Jacobs and Gatewood 1999; Brochway et al. 2000; Wood and Javed 2001). Increased soil water availability and protection from temperature extremes, resulting from increased organic material, were likely the main factors stimulating graminoid production (Harper 1977; Tongway and Ludwig 1996; Champers 2000). Downed woody material can also create obstructions that trap windblown seeds (Fowler 1986; Champers 2000), a process that may have contributed to the slight increases of grass species we observed in the slash-only treatment. Different responses among individual species were noted, though not analyzed, in this study. Further research is needed in order to identify optimal species for understory restoration in pinyon-juniper woodlands.

Seed germination and plant establishment responses are expected to vary with seasonal patterns of soil moisture (Harper et al. 1965; Padien and Lajtha 1992). In our study, precipitation in the second year was two times greater than the decadal average and changes in total plant cover appeared to correspond to the increased moisture. Other studies have also reported positive responses to seeding during years of aboveaverage precipitation (Jacobs and Gatewood 1999; Brochway et al. 2000; Wood and Javed 2001). For example, Jacobs and Gatewood (1999) found no differences in seedling establishment due to slash addition but seeded species increased in all treatments compared to the pretreatment sampling year. Further, others have reported little success in seedling establishment when seeding was done in drought years (Irwin 2006; D. W. Huffman, M. T. Stoddard, P. Z. Fulé, W. W. Covington, and H. B. Smith, unpublished data, 2005). These studies suggest that interannual precipitation is a critical factor in determining seedling fate, regardless of site preparation treatments.

Several studies have indicated that germination and establishment are highly correlated with seed density (Seabloom et al. 2003; Sheley and Half 2006). Based on these findings and low germination rates within pinyon-juniper systems, we elected to seed at a higher rate (10 times greater) than typical land management application. Our intent was to create possible "seed islands" or small patches of established vegetation in hope of facilitating vegetation movement beyond theses patches. In that regard, we would expect higher rates of seeding within these patches to facilitate this movement, though this conceptual framework requires further research. However, seeded grass densities (Fig. 1) were 8 and 11 times greater in the seed-and-slash treatment when compared to seeded treatment at the clay-loam and cinder sites, respectively. Therefore it appears that seed germination and establishment are directly correlated with the number of seeds in favorable microsite seedbeds, rather than the total number of available seeds (Harper et al. 1965; Harper 1977).

\section{Soil Movement}

Scattering slash across plots decreased soil movement at both sites. Soil movement after $2 \mathrm{yr}$ was on average two to three times less in slash treatments compared to nonslash treatments at both sites. These effects were likely due to increases in litter cover, as well as the physical soil barriers provided by branches 


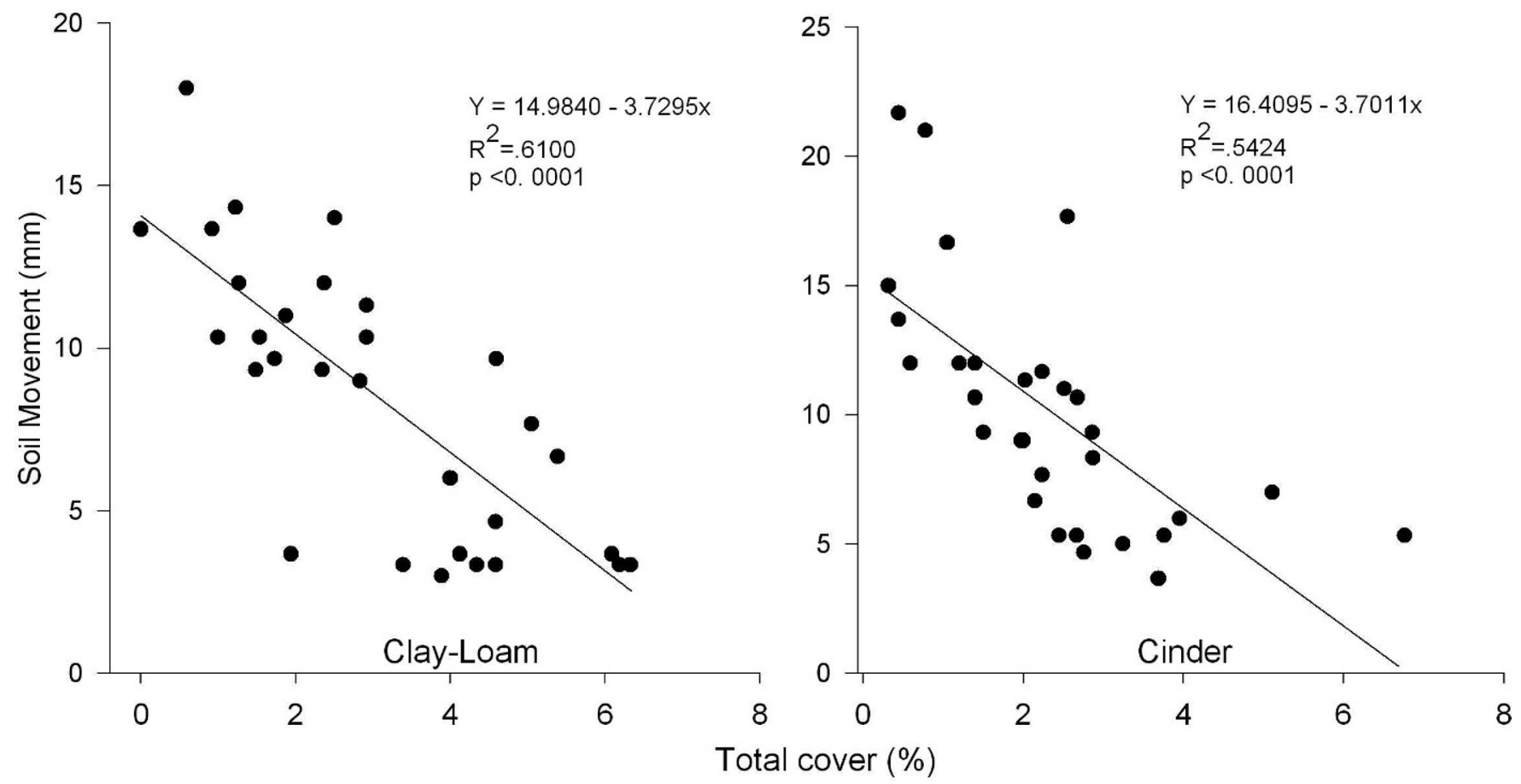

Figure 4. Relationship between the absolute value of soil movement in 2004-2005 and total plant cover (\%) in 2005. Total plant cover (\%) was $\log (n+1)$ transformed. Values plotted are from nonslash plots only $(N=30$ per site).

and limbs. Other studies have reported similar decreases in sediment yield following slash additions (Jacobs and Gatewood 1999; Wood and Javed 2001; Hastings et al. 2003). As with vegetation establishment, soil movement may be expected to vary with seasonal precipitation patterns. For example, we found over four times more soil movement in nonslash plots in 2004 compared to 2005. An increase in total vegetation between years also partially explained this variation. Soil erosion can be highly dependent on variables such as rainfall intensity, slope, scale of monitoring, amount of protective

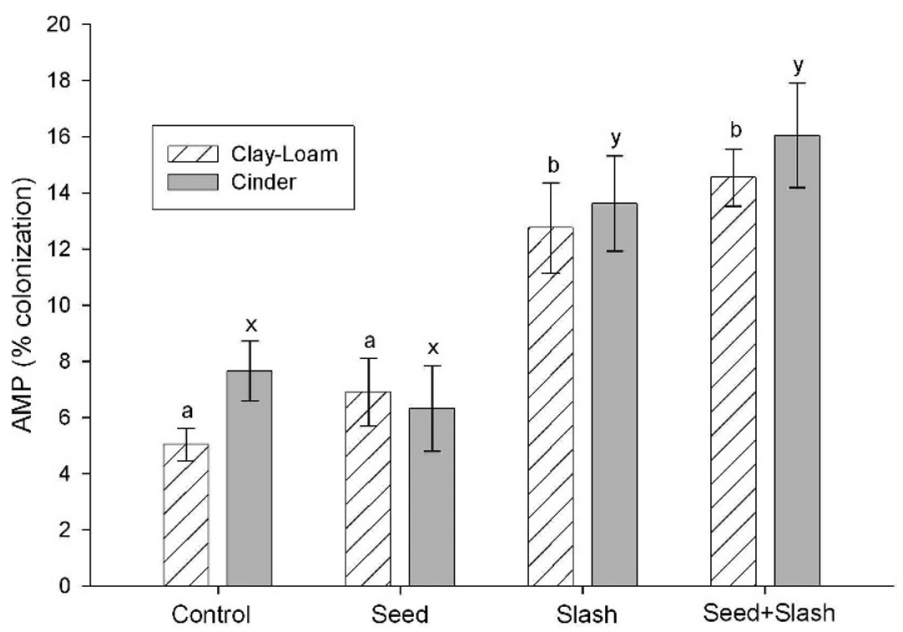

Figure 5. Average potential root colonization by arbuscular mycorrhizal fungi (AMP) under experimental treatments at two different sites in 2004. Different letters index a statistical difference between treatments at $\alpha=0.05$ within each site. Bars represent \pm 1 standard error of the mean $(n=15)$. cover on the soil surface, and soil taxonomy (Wilcox and Breshears 1995; Hastings et al. 2003; Wilcox et al. 2003). Wood et al. (1987) determined total herbaceous ground cover to be the single most important variable in influencing sediment runoff. Similarly, we found vegetation cover to be an important factor in reducing sediment movement at our study sites.

\section{Soil Biota and Chemistry}

Soil biota, particularly AM fungi, have been shown to benefit plants and shape the structure of plant communities by

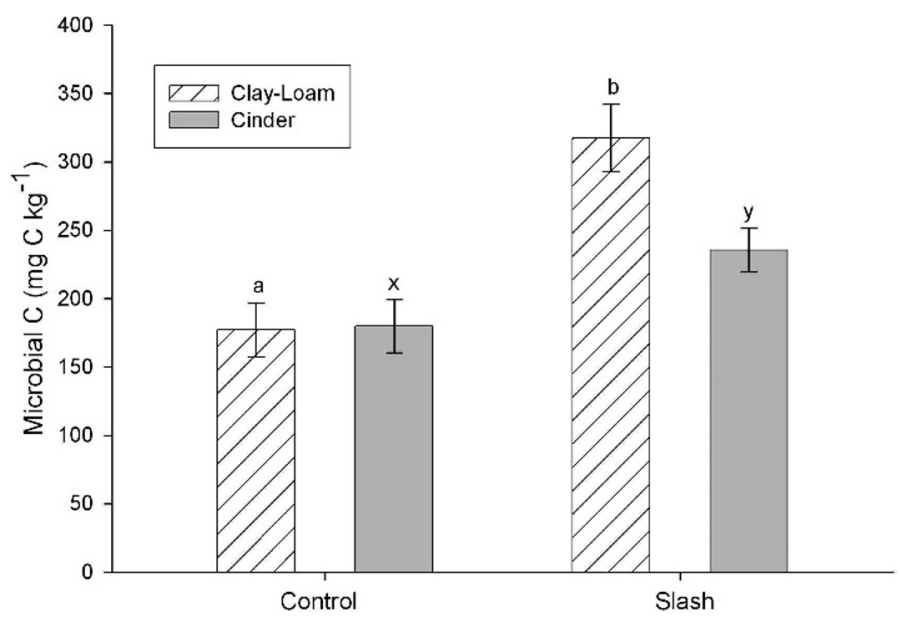

Figure 6. Average microbial carbon $\left(\mathrm{mg} \cdot \mathrm{kg}^{-1}\right)$ under experimental treatments at two different sites in 2004. Different letters index a statistical difference between treatments at $\alpha=0.05$ within a site. Bars represent \pm 1 standard error of the mean $(n=15)$. 
Table 3. Means ( \pm SE) of abiotic soil properties across four treatments in 2003 (pretreatment) and 2004, at two sites ( $n=15)$. For each site, row means indexed by a different letter are significantly different at $\alpha=0.05$.

\begin{tabular}{|c|c|c|c|c|c|c|c|c|}
\hline & \multicolumn{4}{|c|}{ Clay-loam } & \multicolumn{4}{|c|}{ Cinder } \\
\hline & Control & Seed & Slash & Seed + slash & Control & Seed & Slash & Seed + slash \\
\hline \multicolumn{9}{|l|}{ Organic C $\left(\mathrm{g} \cdot \mathrm{kg}^{-1}\right)$} \\
\hline 2003 & $8.4 \pm 0.5$ & $8.0 \pm 0.5$ & $7.9 \pm 0.4$ & $7.5 \pm 0.4$ & $10.8 \pm 0.9$ & $9.2 \pm 0.7$ & $10.6 \pm 0.7$ & $10.5 \pm 0.6$ \\
\hline 2004 & $6.5 \pm 0.5$ & $7.0 \pm 0.5$ & $7.8 \pm 0.5$ & $8.0 \pm 0.5$ & $9.2 \pm 0.9$ & $9.1 \pm 0.9$ & $10.8 \pm 0.7$ & $10.7 \pm 0.6$ \\
\hline \multicolumn{9}{|l|}{ Total $N\left(g \cdot \mathrm{kg}^{-1}\right)$} \\
\hline 2003 & $0.8 \pm 0.03$ & $0.8 \pm 0.02$ & $0.8 \pm 0.02$ & $0.7 \pm 0.03$ & $0.7 \pm 0.07$ & $0.6 \pm 0.04$ & $0.7 \pm 0.05$ & $1.2 \pm 0.05$ \\
\hline 2004 & $0.6 \pm 0.04$ & $0.6 \pm 0.02$ & $0.6 \pm 0.03$ & $0.7 \pm 0.03$ & $0.8 \pm 0.07$ & $0.7 \pm 0.06$ & $0.8 \pm 0.05$ & $0.9 \pm 0.04$ \\
\hline \multicolumn{9}{|l|}{$\mathrm{C}: \mathrm{N}$} \\
\hline 2003 & $10.60 \pm 0.25$ & $10.56 \pm 0.36$ & $10.53 \pm 0.22$ & $10.35 \pm 0.22$ & $14.60 \pm 0.29$ & $14.32 \pm 0.29$ & $14.54 \pm 0.43$ & $14.48 \pm 0.40$ \\
\hline 2004 & $10.83 \pm 0.44$ & $10.88 \pm 0.45$ & $10.98 \pm 0.35$ & $11.61 \pm 0.33$ & $11.96 \pm 0.35$ & $11.95 \pm 0.36$ & $12.60 \pm 0.25$ & $12.34 \pm 0.24$ \\
\hline \multicolumn{9}{|c|}{$\mathrm{NH}_{4}-\mathrm{N}\left(\mathrm{mg} \cdot \mathrm{kg}^{-1}\right)$} \\
\hline 2004 & $0.96 \pm 0.08$ & $1.01 \pm 0.06$ & $0.78 \pm 0.07$ & $0.79 \pm 0.09$ & $1.62 \pm 0.64$ & $0.89 \pm 0.08$ & $0.98 \pm 0.08$ & $1.15 \pm 0.13$ \\
\hline $\begin{array}{l}\mathrm{NO}_{3}-\mathrm{N}\left(\mathrm{mg} \cdot \mathrm{kg}^{-1}\right) \\
\quad 2004\end{array}$ & $2.91 \pm 0.63 \mathrm{a}$ & $2.66 \pm 0.41 \mathrm{a}$ & $0.11 \pm 0.04 b$ & $0.18 \pm 0.07 b$ & $1.16 \pm 0.27 \mathrm{a}$ & $0.86 \pm 0.14 a$ & $0.34 \pm 0.11 b$ & $0.41 \pm 0.15 b$ \\
\hline \multicolumn{9}{|l|}{$\mathrm{pH}$} \\
\hline 2003 & $7.45 \pm 0.10$ & $7.50 \pm 0.13$ & $7.60 \pm 0.13$ & $7.60 \pm 0.09$ & $7.93 \pm 0.08$ & $7.83 \pm 0.06$ & $7.93 \pm 0.08$ & $7.85 \pm 0.05$ \\
\hline 2004 & $7.44 \pm 0.21$ & $7.29 \pm 0.26$ & $7.51 \pm 0.20$ & $7.70 \pm 0.20$ & $7.51 \pm 0.08$ & $7.39 \pm 0.14$ & $7.74 \pm 0.14$ & $7.85 \pm 0.03$ \\
\hline
\end{tabular}

increasing plant uptake of soil nutrients and increasing drought tolerance (Perry et al. 1989; Allen 1991; Gallardo and Schlesinger 1995). In our study, AMP and microbial biomass $\mathrm{C}$ were higher in slash treatments compared to nonslash treatments. Consequently, increases of both AMP and microbial biomass $\mathrm{C}$ may have facilitated the successful establishment of seeded grass species. However, because we did not specifically control for AM fungi and microbial biomass in this study, this conclusion needs further investigation. Other studies have found that AM fungi can promote the establishment of native plant cover in disturbed semiarid ecosystems and suggest a relationship between disturbance recovery time and the abundance of infective propagules of mycorrhizal fungi (Perry et al. 1989; Allen 1991; Requena et al. 2001; Korb et al. 2004). Conversely, AM fungal propagule densities typically remain low after disturbance unless efforts are made to restore them. Slash mulch treatments have been shown to increase microbial populations as a result of increasing nutrient availability (Lundgren 1982; Tongway and Ludwig 1996). In our study, soil chemical properties exhibited no significant changes $1 \mathrm{yr}$ following treatments, although $\mathrm{NO}_{3}-\mathrm{N}$ decreased in the slash treatment compared to the nonslash treatment. This decrease may be related to the immobilization of $\mathrm{NO}_{3}-\mathrm{N}$ through increased microbial activity (Allen 1991; Gallardo and Schlesinger 1995; Murty et al. 1996). Indeed, increasing organic material most likely created an environment that was more conducive to soil biota recruitment.

\section{MANAGEMENT IMPLICATIONS}

Understory conditions of many pinyon-juniper woodlands in the western United States are showing symptoms of degrada- tion likely resulting from overuse and tree competition (Cottam and Stewart 1940; West 1984; Tausch and West 1995; Davenport et al. 1996). Land managers are therefore interested in approaches that may help restore the ecological integrity and biodiversity of theses ecosystems. However, substantial variability in site characteristic and community structure across the range of this vegetation type reduces the ability to generalize about treatment expectations from one woodland community to another. For example, although not rigorously tested in our study, grass establishment under slash treatment appeared to be higher on cinder soils than loamy soils, suggesting soil texture or surface properties likely affect plant emergence and growth (Harper et al. 1965; Winkel et al. 1991; Chambers 2000). Furthermore, not all seeded grass species established equally well in our experiment, thus careful consideration should be given to species performance when choosing seed mixes. In addition, our results demonstrated that surface-sown seeds without additional soil preparation had limited germination success. Finally, climatic factors such as low precipitation and extreme temperature variation are frequent in semiarid woodlands (Betancourt 1996; Swetnam et al. 1999) and exert overriding effects that often determine whether a revegetation project succeeds or fails.

Recent research in various semiarid environments has shown that slash mulch treatments may improve soil conditions and create "islands" of elevated soil fertility, thereby assisting the recovery of degraded plant communities (Tongway and Ludwig 1996; Breshears et al. 1998; Jacobs and Gatewood 1999; Woods and Javed 2001; Brockway et al. 2002; Hastings et al. 2003). Our results confirm that scattered woody material can promote the establishment of grasses, improve soil conditions, and possibly enhance important soil-plant interactions. Thus, it appears these treatments hold promise for contributing to the 
long-term resilience of native plant communities in Southwestern pinyon-juniper woodlands.

\section{ACKNOWLEDGMENTS}

We would like to thank the following individuals for their assistance in the field and laboratory: Luke Brandy, Kristina Rask, Juliana Suby, Brent Tyc, Joe Trudeau, Aleta Rudeen, Erin Brandy, Kelvin Grady, and Lauren Hertz. In addition, we would like to thank Nancy Johnson, Jon Bates, Matt Hurteau, and one anonymous reviewer for valuable comments on the previous drafts of this paper.

\section{LITERATURE CITED}

AlLen, M. F. 1991. The ecology of mycorrhizae. New York, NY, USA: Cambridge University Press. $184 \mathrm{p}$.

ALTSCHUL, J. H., AND H. FaIRLY. 1989. Man, models, and management: an overview of the archaeology of the Arizona Strip and the management of its cultural resources. Washington, DC, USA: US Department of Agriculture Forest Service and US Department of the Interior Bureau of Land Management. Contract 53-8371-6-0054, prepared by Statistical Research, Plateau Archaeology, and Dames and Moore. $410 \mathrm{p}$.

Betancourt, J. L. 1996. Long- and short-term climate influences on southwestern shrublands. In: J. R. Barrow, E. D. McArthur, R. E. Sosebee, and R. J. Tausch [EDS.]. Proceedings. Shrubland ecosystem dynamics in a changing environment. Ogden, UT, USA: US Department of Agriculture, Forest Service, Rocky Mountain Research Station. General Technical Report INT-GTR-338. p. 5-9.

Breshears, D. D., J. W. Nyhan, C. E. Hell, and B. P. Wilcox. 1998. Effects of woody plants on microclimate in a semiarid woodland: soil temperature and evaporation in canopy and intercanopy patches. International Journal of Plant Science 159:1010-1017.

Brockway, D. G., R. G. Gatewood, and R. B. Paris. 2002. Restoring grassland savannas from degraded pinyon-juniper woodlands: effects of mechanical overstory reduction and slash treatment alternatives. Journal of Environmental Management 64:179-197.

Brooks, P. C., A. Landman, G. Pruden, and D. S. Jenkinks. 1985. Chloroform fumigation and the release of soil nitrogen: a rapid direct extraction method to measure microbial biomass nitrogen in soil. Soil Biology and Biochemistry 17:837-842.

Brown, D. E. [ED.]. 1994. Biotic communities of southwestern United States and northwestern Mexico. Salt Lake City, UT, USA: University of Utah Press. $342 \mathrm{p}$.

Brundrett, M. C., And L. K. Aвott. 1994. Mycorrhizal fungus propagules in the jarrah forest. I. Seasonal study of inoculum levels. New Phytologist 127:539-546.

Call, C. A., And B. A. Roundy. 1991. Perspectives and processes in revegetation of arid and semiarid rangelands. Journal of Range Management 44:543-548.

Callaway, R. M. 1995. Positive interactions among plants. Botanical Review $61: 306-349$

Chambers, J. C. 2000. Seed movements and seedling fates in disturbed sagebrush steppe ecosystems: implications for restoration. Ecological Applications 10:1400-1413.

Cottam, W. P., and G. Stewart. 1940. Plant succession as a result of grazing and of meadow desiccation by erosion since settlement in 1862. Journal of Forestry 38:613-626.

Davenport, D. W., B. P. Wilcox, and D. D. Breshears. 1996. Soil morphology canopy and intercanopy sites in a pinon-juniper woodland. Soil Science Society of America Journal 60:1881-1887.

DeWall, A. A. 1993. Soil survey of Shivwits area, Arizona, part of Mohave county. Washington, DC, USA: US Department of Agriculture, Natural Resources Conservation Service. 448 p.
Evans, R. A. 1988. Management of pinyon-juniper woodlands. Ogden, UT, USA: US Department of Agriculture, Forest Service, Intermountain Research Station, General Technical Report INT-249. 34 p.

Floyd, M. L., W. H. Romme, and D. D. Hanna. 2000. Fire history and vegetation patterns in Mesa Verde National Park, Colodado, USA. Ecological Applications 10:1666-1680.

FoWLER, N. L. 1988. What is a safe site? Neighbor, litter, germination date and patch effects. Ecology 69:947-961.

Gallardo, A., and W. H. Schlesinger. 1995. Factors determining soil microbial biomass and nutrient immobilization in desert soils. Biogeochemistry 28:55-68.

Grady, K. C., AND S. C. HART. 2006. Influences of thinning, prescribed burning, and wildfire on soil processes and properties in southwestern ponderosa pin forest: a retrospective study. Forest Ecology and Management 234: 123-135.

HARPER, J. L. 1977. Population biology of plants. London, UK: London Academic Press. $892 p$

Harper, J. L., J. T. Williams, and G. R. Sagar. 1965. The behavior of seeds in soil. I. The heterogeneity of soil surfaces and its role in determining the establishment of plants from seed. Journal of Ecology 53:273-286.

Harris, A. T., G. P. Asner, and M. E. Miller. 2003. Changes in vegetation structure after long-term grazing in pinyon-juniper ecosystems: integrating imaging spectroscopy and field studies. Ecosystems 6:368-383.

Hastings, B. K., F. M. SMith, AND B. F. JacoBs. 2003. Rapidly eroding piñon-jjuniper woodlands in New Mexico: response to slash treatment. Journal of Environmental Quality 32:1290-1298.

Herman, R. P., K. P. Provencio, J. Herrera-Matos, and R. J. Torrez. 1995 Resource islands predict the distribution of heterotrophic bacteria in Chihuahuan Desert soils. Applied and Environmental Microbiology 61: 1816-1821.

Horman, C. S., and V. J. Anderson. 2003. Understory species response to Utah juniper litter. Journal of Range Management 56:68-71.

IRWIN, M. R. 2006. Effects of slash arrangements and treatments on the pinyonjuniper woodland understory community [thesis]. Flagstaff, AZ, USA: Northern Arizona University. $111 \mathrm{p}$.

JacoBs, B. F., and R. G. Gatewood. 1999. Restoration studies in degraded pinyonjuniper woodlands of north-central New Mexico. In: S. B. Monsen and R. Stevens [EDS.]. Proceedings: ecology and management of pinyon-juniper communities within the Interior West. Ogden, UT, USA: US Department of Agriculture, Forest Service, Rocky Mountain Research Station, RMRS-P-9. p. 294-298.

JAMESON, D. A. 1970. Degradation and accumulation of inhibitory substances from Juniperus osteosperma (Torr.) Little. Plant and Soil 33:213-224.

Jameson, D. A., J. A. Williams, and E. W. Wilton. 1962. Vegetation and soils of Fishtail Mesa, Arizona. Ecology 3:403-410.

Johnson, N. C., T. E. O'Dell, and C. S. Bledsoe. 1999. Methods for ecological studies of mycorrhizae. In: G. P. Robertson, D. C. Coleman, C. S. Bledsoe, and P. Sollin [EDS.]. Standard soil methods for long-term ecological research. New York, NY, USA: Oxford University Press. p. 378-411.

KonIAK, S., AND R. L. EverTT. 1982. Seed reserves in soils of successional stages of pinyon woodlands. American Midland. Naturalist 108:295-303.

Korb, J., N. C. Johnson, And W. W. Covington. 2004. Slash pile burning effects on soil biotic and chemical properties and plant establishment: recommendations for amelioration. Restoration Ecology 12:52-62.

KUEHL, R. 0. 1994. Statistical principles of research design and analysis. Belmont, CA, USA: Wadsworth Publishing Company. 686 p.

LUdWIG, J. A., AND J. F. ReYNolds. 1988. Statistical ecology: a primer on methods and computing. New York, NY, USA: Wiley-Interscience. $337 \mathrm{p}$.

LunDGReN, B. 1982. Bacteria in a pine forest soil as affected by clear-cutting. Soil Biology and Biochemistry 14:537-742.

Mlller, R. F., and R. J. Tausch. 2001. The role of fire in juniper and piñon woodlands: a descriptive analysis. In: K. E. M. Galley and T. P. Willson [EDs.]. Invasive species workshop: the role of fire in the control and spread of invasive species. Tallahasee, FL, USA: Tall Timbers Research Station. $p$. $15-30$. 
Murty, D., R. E. McMurtrie, and M. G. Ryan. 1996. Declining forest productivity in aging forest stands: a modeling analysis of alternative hypotheses. Tree Physiology 16:187-200.

Padien, D. J., and K. Lajtha. 1992. Plant spatial pattern and nutrient distribution in pinyon-juniper woodlands along an elevational gradient in northern New Mexico. International Journal of Plant Sciences 153(3):425-433.

Parkinson, J. A., And S. E. Allen. 1975. A wet oxidation procedure suitable for the determination of nitrogen and mineral nutrients in biological material. Community Soil Science and Plant Analysis 6:1-11.

Perry, D. A., M. P. Amaranthus, J. G. Borchers, S. L. Bouchers, and R. E. Brainerd. 1989. Bootstrapping in ecosystems. BioScience 39:230-237.

Pieper, R. D. 1990. Overstory-understory relations in pinyon-juniper woodlands in New Mexico. Journal of Range Management 43:413-415.

Poulsen, C. L., S. C. Walker, and R. Stevens. 1999. Soil seed banking in pinyonjuniper areas with differing levels of tree cover, understory density and composition. In: S. B. Monsen and R. Stevens [EDS.]. Proceedings: ecology and management of pinyon-juniper communities within the Interior West. Ogden, UT, USA: US Department of Agriculture, Forest Service, Rocky Mountain Research Station, RMRS-P-9. p. 141-145.

Requena, N., E. Perez-Solis, C. Azcón-Aguilar, P. Jefreiles, and J. Barea. 2001. Management of indigenous plant-microbe symbioses aids restoration of desertified ecosystems. Applied and Environmental Microbiology 67:495-498.

Romme, W. H., L. Floyd-Hanna, and D. Hanna. 2003. Ancient pinyon-juniper forests of Mesa Verde and the West: a cautionary note for forest restoration programs. In: P. N. Omi and L. A. Joyce [EDs.]. Proceedings: fire, fuel treatments, and ecological restoration: conference proceedings. Ft. Collins, CO, USA: US Department of Agriculture, Forest Service, Rocky Mountain Research Station, RMRS-P-9. p. 335-350.

Schlesinger, W. H., J. F. Reynolds, G. L. Cunningham, L. F. Jarrell, R. A. Virgina, and W. G. WhitFord. 1990. Biological feedbacks in global desertification. Science 247:1043-1048.

Schmutz, E. M., C. C. Michaels, and B. I. Judd. 1967. Boysag Point: a relict area on the north rim of Grand Canyon in Arizona. Journal of Range Management 20:363-369.

Seabloom, E. W., E. T. Borer, V. L. Boucher, R. S. Burton, K. L. Cottingham, L. Goldwasser, W. K. Gram, B. E. Kendall, and F. Micheli. 2003. Competition, seed limitation, disturbance, and reestablishment of California native annual forbs. Ecological Applications 13:575-592.

Shakesby, R. A. 1993. The soil erosion bridge: a devise for micro-profiling soil surface. Earth Surface Process and Landforms 18:823-827.

Sheley, R. L., And M. L. Half. 2006. Enhancing native forb establishment and persistence using a rich seed mixture. Restoration Ecology 14:627-635.

Swetnam, T. W., C. D. Allen, and J. L. Betancourt. 1999. Applied historical ecology: using the past to manage for the future. Ecological Applications 9:1189-1206.

$\mathrm{T}_{\mathrm{AuSCH}}$, R. J. 1999. Historic pinyon and juniper woodland development. In: S. B. Monsen and R. Stevens [EDS.]. Proceedings: ecology and management of pinyon-juniper communities within the Interior West. Ogden, UT, USA: US Department of Agriculture, Forest Service, Rocky Mountain Research Station, RMRS-P-9. p. 12-19.
TAusch, R. J., and N. E. West. 1995. Plant species composition patterns with differences in tree dominance on a southwestern Utah piñon juniper site. In: D. W. Shaw, E. F. Aldon, and C. LoSopio [EDS.]. Proceeding: desired future conditions for piñon-juniper ecosystems. Ft. Collins, CO, USA: US Department of Agriculture, Forest Service, Rocky Mountain Research Station, General Technical Report RMRS-258. p. 16-23.

Tausch, R. J., N. E. WeSt, and A. A. Nabi. 1981. Tree age and dominance patterns in Great Basin piñon-juniper woodlands. Journal of Range Management 34:259-264.

Thatcher, A. P., and V. L. Hart. 1974. Spy Mesa yields better understanding of pinyon-juniper in range ecosystem. Journal of Range Management 27:354-357.

Tongway, D. L., And J. A. Ludwig. 1996. Rehabilitation of semiarid landscapes in Australia. I. Restoring productive soil patches. Restoration Ecology 4:388-397.

us Department of Agriculture natural Resources Conservation Service. 2004. The PLANTS Database, Version 3.5 Baton Rouge, LA, USA: National Plant Data Center. Available at: http://plants.usda.gov. Accessed 1 May 2007.

Vierheilin, H., A. P. Coughlan, U. Wyss, and Y. Piche. 1998. Ink and vinegar, a simple staining technique for arbuscular-mycorrhizal fungi. Applied and Environmental Microbiology 64:5004-5007.

Weisberg, P. J., E. Lingua, and R. B. Pillar. 2007. Spatial patterns of pinyon-juniper woodland expansion in Central Nevada. Rangeland Ecology and Management 60:115-124.

WEST, N. E. 1984. Successional patterns and productivity potentials of pinyonjuniper ecosystems. In: United States National Research Council [ED.]. Developing strategies for rangeland management. Boulder, CO, USA: Westview Press. p. 1301-1332.

WeSt, N. E. 1999. Juniper-piñon savannas and woodlands of western Northern America. In: R. C. Anderson, J. S. Fralish, and J. M. Baskin [EDS.]. Savannas, barrens and rock outcrops: plant communities of North America. New York, NY, USA: Cambridge University Press. p. 288-308.

WiLcox, B. P., AND D. D. BReshears. 1995. Hydrology and ecology of pinyon-juniper woodlands: conceptual framework and field studies. In: D. W. Shaw, E. F. Aldon, and C. LoSopio [EDS.]. Proceeding: desired future conditions for piñon-juniper ecosystems. Flagstaff, AZ, USA: US Department of Agriculture, Forest Service, Rocky Mountain Research Station, RMRS-258. p. 109-119.

Wilcox, B. P., D. D. Breshears, and C. D. Allen. 2003. Ecohydrology of a resourceconserving semiarid woodland: effects of scale and disturbance. Ecological Monographs 73:223-239.

Winkel, V. K., B. A. Roundy, And J. R. Cox. 1991. Influence of seedbed microsite characteristics on grass seedling emergence. Journal of Rangeland Management 44:210-214.

Wood, J. C., M. K. Wood, and J. M. Tromble. 1987. Important factors influencing water infiltration and sediment production on arid lands in New Mexico. Journal of Arid Environments 12:111-118.

Wood, M. K., AND N. JAVED. 2001. Hydrologic and vegetal responses to fuelwood harvest and slash disposal in a pinyon pine and juniper dominated grassland. Las Cruces, NM, USA: New Mexico State University, New Mexico Water Resources Institute, Report No. M27. 29 p. 